\title{
Teaching and Learning of Visual Arts in Senior High Schools in Rural and Urban Settings in Ghana
}

\author{
Abena Okyerewa ${ }^{1}$, Siaw Samuel Nortey ${ }^{2}$, Edwin K. Bodjawah ${ }^{3}$ \\ ${ }^{1}$ Faculty of Creative Art and Technology, Kumasi Polytechnic, Kumasi, Ghana \\ Email:odettegh@yahoo.co.uk \\ ${ }^{2}$ Department of Industrial Art, Kwame Nkrumah University of Science and Technology, Kumasi, \\ Ghana,Email:sammynort@gmail.com \\ ${ }^{3}$ Department of Painting and Sculpture, Kwame Nkrumab University of Science and Technology, Kumasi, \\ Ghana,Email:edwino4u@yaboo.com
}

\begin{abstract}
This study used qualitative and quantitative research methods in tandem to compare teaching and learning processes to illuminate differences in students' academic performance gap in the Visual Arts in urban, peri-urban and rural Senior High Schools in the Ashanti Region. With the use of purposive and simple random sampling techniques, a sample of six schools two in each setting, comprising 120 students and 18 teachers were selected for in-depth study. The study found that urban schools perform better than rural schools because they have prestigious names and character, more qualified teachers, and they attract and admit high performance BECE applicants into the Visual Arts department. The study revealed that the geographical settings of the school and educational opportunities directly influence the academic performance and achievement of students. Environmental factors, lack of studio facilities, and differences in teaching methodologies in the different geographical settings seem to influence students' learning and performance.
\end{abstract}

Keywords: Teaching and learning; Visual arts; Rural and urban education; Academic performance.

\section{Introduction}

The educational system of any nation is a mirror through which the image of the nation can be seen, shaped and also likely to be shaped. Education, according to many authors, has been and will continue to be the potential cause of change in any society. Education is also meant to develop manpower for different levels of the economy which is an ultimate guarantee of national self-reliance. Hence, the formulation and clarification of purposeful education must emerge from the realities of life, when the entire scope of human life is taken into consideration and at the same time, specific needs of the individual are considered (Von Glasersfeld, 1995; Singh and Rana, 2004). According to Ryan \& Cooper (1992), little has changed in secondary education over the last 100 years. A change of courses has been made but little changes have occurred in living patterns, values, technologies and careers. Also, changes have emerged from examinations, school programmes, subject delivery and the end product of school learning. To get abreast of the little changes that have emerged and to recognize school learning as an evolving process, secondary schools offer a wide range of programme models to meet the needs of students. The secondary education curriculum, according to Nyman and Jenkins (1999), revolves around subjects offered in the World War I era and are being taught by specialists.

According to UNICEF (1990), Ghana has made better than average efforts to formulate national development plans with different strategies being pursued to raise the living standards of the population and to ensure economic growth. Yet, the urban-biased character of past approaches has left a legacy of extreme disparities in development which reflects in differences between rural and urban areas in terms of demographic and settlement pattern, distribution of social infrastructure and levels of economic activity.

In Ghana, students in urban as well as rural Senior High Schools (SHS) follow the same curriculum and prescribed syllabi; therefore, they operate under the same regulations of teaching and learning. With the knowledge that schools exist in all parts of the country, it is expected that all other things 
being equal, students, irrespective of the community they live in, should do well in school. However, it appears performance is at variance with this view. This makes it difficult for parents to accept to have their wards enroll in schools located in rural communities. Despite the government's intervention of distributing SHS applicants fairly across the country through the Computerized School Placement System, parents and guardians try as much as possible to bring their wards who have been placed in rural schools back to urban and the famous schools. It is important that this issue is examined through comparison of the teaching and learning processes in Visual Arts subjects in selected urban and rural settings to enable us ascertain the factors that account for this situation.

Can this be attributed to the difference in locations and the environments of the schools, or is it that other inferential factors are included? The need to understand these observations, assumptions and personal experience of the apparent urban-rural disparity in student academic achievement makes it very necessary for us to find out the relevant factors that affect teaching, learning and academic performance of the Visual Arts students in the different geographic settings in the Ashanti Region, Ghana. In this study (which reflects a wider consensus) peri-urban school is defined as a school lying at the peripherals of a major town.

\subsection{Education in Ghana}

Ghanaian schools are characterized as good, average or poor; whether public or private; rural or urban. The grading of schools is done in accordance with quality of output and internal performance of schools as seen through students communication skills depend on the quality of output and internal performance of schools with indicators basically measured by students' communication skills and examination results of the pupils or students communication skills and examination results. The schools are largely characterized by large class sizes in the urban and peri-urban areas - up to 70 students per class, but 30 or less students per class in rural schools. While rural schools lack good infrastructure and acilities, have low enrolment, less qualified teachers and fewer textbooks and other teaching and learning materials, urban schools are generally over-staffed with qualified teachers, are over-enrolled, better funded and monitored, have better infrastructure and adequate resources to work with (Opoku-Asare, 2000). The rural-urban disparity impinges directly on teaching and learning output and hence, pupils' academic achievement as well. Though the schools are generally seen as similar, only background knowledge of the routines and related regularities associated with schools will enable the outsider to appreciate better what shapes the lives of those who work in them.

Opoku-Asare (2000) reports that the school system in Ghana is also characterized by uniform adoption of textbooks and mixed ability teaching. Teaching is also characterized by the transmission of information, a model that takes its roots from the traditional oral culture outside the school. This telling model of teaching according to King (1990) is the dominant method adopted by many teachers and involves much "pouring in" of knowledge. The teacher is, therefore, a very significant factor in school education and student achievement. Besides, the Ghanaian school system has an agenda of examinations that deeply affect the organisation of teaching and learning, selection for and mobility through the grades, passing out rates, qualifying credentials and employment for those who enroll in school and consequently, the value and significance of education.

Secondary education occurs in Junior and Senior High Schools. Junior High education follows a six year Primary education and lasts for three years. At the end of the period, students take the national Basic Education Certificate Examination (BECE) which qualifies them to be considered for admission into Senior High Schools of their choice to pursue specialized programmes, Students are required to fill forms to choose schools (Page, 2007).

\subsection{The Senior bigh school visual arts curriculum}

The Visual Arts curriculum followed in Senior High Schools consists of eight subjects: Basketry, Jewellery, Ceramics, Graphic Design, Leatherwork, Picture Making, Sculpture, Textiles, and a compulsory General Knowledge in Art (GKA). The choice of programme depends on resources available in each school's area of location. According to the Teaching Syllabus for Visual Arts (2008), each student opts to study three out of the eight subjects: one or two electives from the two-dimensional category (Group A) depending on the school's resources and one from the three-dimensional category (Group B) in addition to General Knowledge in Art which is studied by all Visual Arts students. Successful students after the West African Secondary School Certificate (WASSCE) are able to access higher education. The syllabus for these course areas has been designed in 
such a way as to provide students who study the courses have adequate foundation knowledge and skills for further education in the respective Visual Art disciplines as well as for self-employment or apprenticeship for those terminating their education at SHS in the respective disciplines (CRDD, 2008).

\section{Methodology}

The probability and non-probability sampling techniques of quantitative and qualitative research approaches were used in the selection of samples for the study. Initially, the cluster sampling technique was employed to categorise the schools into rural, periurban and urban schools on the basis of the Ghana Education Service approved classification of schools in Ashanti Region. This technique made it possible for the researcher to investigate the perceived urban rural disparity in Visual Arts education in Senior High Schools in the region. After the schools had been clustered into the three categories, the purposive and simple random sampling techniques were used simultaneously to identify and select a number of schools, teachers and students on whom to base the study. The purposive sampling technique ensured that only teachers and students in the Visual Arts department were selected. The simple random technique ensured that all class levels in the selected schools had equal chances of being selected for indepth study.

According to GES records, there are 89 public Senior High Schools in the Ashanti Region. Of the number, 42 (or 47.9\%) offer Visual Arts with 18 $(42.9 \%)$ of them located in the Kumasi Metropolis. A sample of six single-sex and mixed-sex schools representing urban, peri-urban and rural settings was selected for in-depth study. The sample comprised two schools in each of the three locations. The study respondents consisted of 18 teachers and 120 students. Each participating school, therefore, provided three teachers and 20 students.

\section{Results and discussion}

\subsection{Logistic support}

The fieldwork revealed a relative lack of logistics in almost all the selected schools. Lack was measured by the availability of logistics including art studio, working tables and funding for practical works for the term. The urban schools had relatively greater access to logistics than the peri-urban and rural schools.
Although working table was reported to be the most available logistic, a significant majority (63.7\%) of the student respondents indicated that they do not have working tables in their schools. The responses are shown in Table 1 below.

Table 1

Location and availability of working table

\begin{tabular}{|c|c|c|c|c|c|c|c|}
\hline \multirow{3}{*}{$\begin{array}{l}\text { Availability of } \\
\text { Working Table }\end{array}$} & \multicolumn{6}{|c|}{ Location of School } & \multirow{3}{*}{ Total } \\
\hline & \multicolumn{2}{|c|}{ Urban } & \multicolumn{2}{|c|}{ Peri-urban } & \multicolumn{2}{|l|}{ Rural } & \\
\hline & Freq & $\%$ & Freq & $\%$ & Freq & $\%$ & \\
\hline Yes & 20 & 50.0 & 14 & 36.8 & 6 & 17.6 & $\begin{array}{l}40 \\
(5.7 \%)\end{array}$ \\
\hline NO & 20 & 50.0 & 24 & 63.2 & 28 & 82.4 & $\begin{array}{l}72 \\
\text { (64.3\%) }\end{array}$ \\
\hline Total & 40 & 100 & 38 & 100 & 34 & 100 & $\begin{array}{l}112 \\
(100 \%) \\
\end{array}$ \\
\hline
\end{tabular}

Majority of the teachers (58.8\%) reported they had no working tables in their schools. The data assumed that the further away a school is from the urban centre the least likely they are to have the most basic of the Visual Arts department's need. This conclusion was made evident by the fact that the number of respondents who answered 'Yes' to the question of availability of this facility reduced from 20 $(50 \%)$ in the urban schools to $14(36.8 \%)$ in the periurban to $7(20 \%)$ in the rural schools. It is evident here that working tables are least available in rural schools.

From the Table 2 below, the study revealed that in the absence of working tables, most of the students $(77.0 \%)$ use their classroom desks, dining hall tables $(14.8 \%)$ and unused tables on the compound (8.2\%) for practical work. The students also affirmed that classroom desks are the most used alternative (50.0\%) by the teachers for practical classes. This confession shows that both teachers and students frequently use classroom desks which obviously are uncomfortable, rough and not suitable for art making purposes, hence, the possibility of no quality work will be produced at the end.

Table 2

Alternatives to working table

\begin{tabular}{l|lll|l}
\hline \multirow{2}{*}{$\begin{array}{l}\text { Alternatives to } \\
\text { Working Table }\end{array}$} & \multicolumn{2}{l|}{ Students } & \multicolumn{2}{l}{ Teachers } \\
\cline { 2 - 6 } & Frequency & Percent & Frequency & Percent \\
\hline Classroom desk & 47 & 77.0 & 5 & 50.0 \\
Dining Hall table & 9 & 14.8 & 3 & 30.0 \\
Unused tables & 5 & 8.2 & $\mathbf{2}$ & $\mathbf{2 0 . 0}$ \\
\hline Total & $\mathbf{6 1}$ & $\mathbf{1 0 0}$ & $\mathbf{1 0}$ & $\mathbf{1 0 0}$ \\
\hline
\end{tabular}

Source: Fieldwork, 2009 
While $17.7 \%$ of the students affirmed they have access to art studio in their schools, an overwhelming $82.3 \%$ of them indicated they do not have access to art studios in their schools. Similarly, a significant majority of $76.5 \%$ of the teachers also indicated that they do not have art studios in their schools. Further statistical analysis indicates that the differences found in the availability of art studios in the three locations were statistically significant $\mathrm{x}^{2}(2)=0.02$; $\mathrm{p}=0.022$. Thus location of the school does not really influence the availability of the art studio. Schools generally have poor access to art studio facility. Accordingly, availability of art studio, in order from the most to the least available are: peri-urban, urban and rural. The details are provided in Table 3.

Table 3

Location and availability of art studio

\begin{tabular}{|c|c|c|c|c|c|c|c|}
\hline \multirow{3}{*}{$\begin{array}{l}\text { Availability of } \\
\text { Art Studio }\end{array}$} & \multicolumn{6}{|c|}{ Location of School } & \multirow{3}{*}{ Total } \\
\hline & \multicolumn{2}{|c|}{ Urban } & \multicolumn{2}{|c|}{ Peri-urban } & \multicolumn{2}{|c|}{ Rural } & \\
\hline & Freq & $\%$ & Freq & $\%$ & Freq & $\%$ & \\
\hline Yes & 6 & 14.6 & 10 & 26.3 & 4 & 11.8 & 20 \\
\hline NO & 35 & 85.4 & 28 & 73.7 & 30 & 88.2 & 93 \\
\hline Total & 41 & 100 & 38 & 100 & 34 & 100 & 113 \\
\hline
\end{tabular}

Source: Fieldwork, 2009

With regard to the supply of most school infrastructure, the rural areas recorded the least available art studio with $11.8 \%$ responses. In dealing with the lack of art studio, the alternative resources used by the students include: classroom, outside the classroom and home spaces. For the teachers, none worked at home as an alternative to the absence of art studio. The most used alternative among the teachers (as many as $84.6 \%$ ) is the classroom space.

According to the student respondents, the least provided logistic in the selected schools is funding. Only $13.4 \%$ of the selected students indicated that their schools provide funds for their programmes with $86.6 \%$ indicating they do not have access to funding For the teachers, majority of them $(58.8 \%)$ indicated . that their departments do not provide funds for the Visual Arts programme. This number is lower than that of the students. The study indicates that compared to the urban areas, there is no significant distinction between the peri-urban and the rural areas in terms of provision of funds for the Visual Arts Department.

Table 4 indicates that urban schools are relatively better financed $17.1 \%$ of them responding in the affirmative. However, the differences $(17.1 \%$ vs. $10.8 \%$ vs $11.8 \%$ ) were not statistically significant $\mathrm{x}^{2}(2)$ $=0.769 ; \mathrm{p}=0.68$. For the peri-urban and rural schools, there were no significant differences between their respective responses $(10.8 \%$ and $11.8 \%)$ answer in affirmative.

Table 4

Location and availability of funds

\begin{tabular}{|c|c|c|c|c|c|c|c|}
\hline \multirow{3}{*}{$\begin{array}{l}\text { Availability of } \\
\text { Funds }\end{array}$} & \multicolumn{6}{|c|}{ Location of School } & \multirow{3}{*}{ Total } \\
\hline & \multicolumn{2}{|c|}{ Urban } & \multicolumn{2}{|c|}{ Peri-urban } & \multicolumn{2}{|c|}{ Rural } & \\
\hline & Freq & $\%$ & Freq & $\%$ & Freq & $\%$ & \\
\hline Yes & 7 & 17.1 & 4 & 10.8 & 4 & 15 & 15 \\
\hline NO & 34 & 82.9 & 33 & 89.1 & 30 & 88.2 & 97 \\
\hline Total & 41 & 100 & 37 & 100 & 34 & 100 & 112 \\
\hline
\end{tabular}

Source: Fieldwork, 2009

The questionnaire revealed alternative sources of funding as Class contribution, Personal contribution, Teachers and students' contribution. The study indicates that majority of the students (71.3\%), in the personal financial contributions to purchase materials for practical work. absence of funding from their departments, make 


\subsection{Teaching and teaching methods}

\section{Educational qualification of teachers}

The study revealed that most teachers have a minimum of a first degree qualification while $35.3 \%$ of them have Master's Degree. This level of qualification attests to a generally high standard of education for the teachers; but as to how higher education translates into effective teaching in the various Visual Arts subjects is another researchable issue that lies outside the objectives of this paper. Some variations were observed in the educational qualifications of the teachers in the three study areas; the variations are represented on Table 5 below. The table shows that the number of teachers in the rural areas is almost the same as that of the peri-urban area. While the urban schools have more teachers with master's degree, the rural schools have none. The data reflects the ruralurban disparity in resources reported by OpokuAsare (2000). This disparity suggests that not much has changed in the distribution of educational resources since this last study.

Table 5

Location and educational qualification of teachers

\begin{tabular}{|c|c|c|c|c|c|c|}
\hline \multirow{3}{*}{ Qualification } & \multicolumn{6}{|c|}{ Location of School } \\
\hline & \multicolumn{2}{|c|}{ Urban Area } & \multicolumn{2}{|c|}{$\begin{array}{l}\text { Peri-urban } \\
\text { Area }\end{array}$} & \multicolumn{2}{|c|}{ Rural Area } \\
\hline & Freq & $\%$ & Freq & $\%$ & Freq & $\%$ \\
\hline First Degree & 1 & 16.7 & 3 & 60.0 & 5 & 83.3 \\
\hline $\begin{array}{l}\text { Postgraduate } \\
\text { Diploma }\end{array}$ & 1 & 16.7 & 0 & 0.0 & 1 & 16.7 \\
\hline Master's degree & 4 & 66.6 & 2 & 40.0 & 0 & 0.0 \\
\hline Total & 6 & 100 & 5 & 100 & 6 & 100 \\
\hline
\end{tabular}

Source: Fieldwork, 2009

As indicated in Table 5, it could be inferred that the urban schools receive more highly qualified teachers who ensure effective teaching and learning than rural schools receive. The presence of many teachers with higher education qualifications also suggests that the students are receiving effective teaching if their exposure to university graduates is taken into consideration.

In addition the higher qualifications urban teachers have, the study revealed that most of the teacher respondents have classroom teaching experience that ranges from three years to more than 20 years. Very few of the respondents $(6 \%)$ have less than three years of teaching experience while a significant of $70 \%$ of them have more than 10 years of teaching experience. The length of years teachers have served in the classroom suggests the possibility of them acquiring much knowledge and expertise in sharing, coaching and mentoring of younger teachers, and their active involvement in decision making in he schools as well as their use of rich teaching experience to help the less experienced teachers to raise academic levels of their students. Table 6 shows a relatively fair distribution of experienced teachers in the urban, peri-urban and rural schools.

Table 6

Location and work experience of teachers

\begin{tabular}{l|l|l|l|l|l|l}
\hline \multirow{2}{*}{ Duration } & \multicolumn{9}{l}{ Location of School } \\
\cline { 2 - 8 } & \multicolumn{4}{l}{ Urban } & \multicolumn{3}{l|}{ Peri-urban } & \multicolumn{2}{l}{ Rural } \\
\cline { 2 - 8 } & Freq & $\%$ & Freq & $\%$ & Freq & $\%$ \\
\hline Below 3 vears & 0 & 0.0 & 1 & 20.0 & 0 & 0.0 \\
4-10 years & 1 & 16.7 & 0 & 0.0 & 3 & 50 \\
11-20 vears & 3 & 50.0 & 2 & 40.0 & 1 & 16.7 \\
Above 21 vears & 2 & 33.3 & 2 & 40.0 & 2 & 33.3 \\
\hline Total & 6 & 100 & 5 & 100 & 6 & 100 \\
\hline
\end{tabular}


From Table 6, while both the urban and periurban schools have $83 \%$ and $80 \%$ of the teachers responding they have taught for over 10 years, only half of the teachers in rural schools have taught for up to 10 years. The implication is that teachers in both urban and peri-urban areas are more experienced to provide effective teaching and learning than their counterparts in the rural schools.

When teachers lack the background knowledge and qualification in Art education, it is obvious they will have little or no idea of the various methods of teaching and how they apply them in classroom or art studio teaching. This deduction confirms Amissah et al's (2002) assertion that teaching does not depend on the learner any more than learner depending on the teacher.

The study found that all the teachers in the selected schools use the same method of teaching in the classroom. But according to James (1996), technical demonstration by teachers teaches students the nature of creative art and helps students go beyond school learning. This method of teaching practical work as a theory lesson by teachers does not fulfill the rationale for the programme which is to equip the student with the necessary creative skills and acquisition of competency (CRDD, 2008). The teachers in the sampled schools complained that the teaching periods allocated to their subjects are not enough and this makes it difficult for them to arrange practical and studio lessons.

As Short et al (1991) and Crocker (1991) indicate, teachers have control over seatwork, drills and practical exercise. This control maximizes achievement when teachers emphasise academic instruction as their main goal. Wiggins and McTighe (2005) also confirm that the more specific facts, concepts and skills are taught, the larger the ideas and processes gained. The study revealed that even though there were no studios for the various subjects, some of the Visual Arts teachers organise practical lessons under trees on the school compounds for their students during leisure times.

This innovation confirms Hayford's (1998) observation that Ghana has examples of teachers who have redefined their teaching roles or responsibilities with the view of making a difference. Non-resident masters may not be able to show the ingenuity in lesson delivery; and the day students may not benefit from some practical lessons.

In observing teaching and learning processes in the sampled schools, the following indicators were used: learning methods, frequency of lessons and frequency of practical lessons. The study found that $70.6 \%$ of the teachers use between 11 and 20 periods a week for teaching while $23.5 \%$ of them teach more than 21 periods a week. The implication is that those with enough instructional periods have more time for both practical and theory lessons as the syllabus demands. The findings did not reveal any significant differences in the correlation between the location and the number of teaching periods of the sampled teachers. However, the rural areas came up as the location where quite a significant percentage of teachers $(16.7 \%)$ have below 11 teaching periods per week.

From the study, most of the respondents as many as $76.5 \%$ indicated that the periods are enough for their lessons. The number of teachers who indicated that their teaching periods are not enough forms $23.5 \%$ of the respondents. Although this is in the minority, the figure is quite significant as the data reveal that most of the schools have six teaching periods for each of the three Visual Arts electives; the least number of periods being five hours. This number of periods indicates that practical lessons are inadequate.

The study shows that to a large extent, teachers use most of the contact hours effectively with as many as $82.6 \%$ of the student respondents indicating that their teachers use up all the lesson periods. The study further shows that the likelihood that a teacher will utilise all the lesson hours is highest in peri-urban schools in comparison with urban and rural schools. This finding indicates that teachers in urban schools are less likely to utilise their allotted contact hours. This is attested to by $23.1 \%$ of the students and $86.5 \%$ for the peri-urban schools. Practical lessons in Visual Arts education are so important that the under utilization of allotted time for the lessons will negatively affect the performance of the students.

The study also revealed that as many as $69.9 \%$ of the students indicated that they have between one to three practical lessons per term while $50.5 \%$ of the students indicated that they have practical lessons only once in a term. However, a quarter of the students indicated that they have more than five practical lessons in a term. The data $(67.9 \%$ respondents) further showed that the possibility for students to have a single practical lesson per term is highest in rural schools. The most important reasons given by the students for choosing a particular learning method was the need to acquire different ideas and understanding.

On the issue of specialisation of teaching, the responses are that majority of them $(57 \%)$ are teaching in their specialised subject areas with $43 \%$ of them 
teaching different subjects they did not specialised in. The comparison between what the teachers are currently teaching and the Visual Arts areas they specialized in as revealed from the interviews showed that all the teachers in the urban schools are teaching in their specialised disciplines. While $25 \%$ of teachers in the peri-urban area are teaching their specialized subjects; the large majority of the total (75\%) was found to be teaching different subjects. The teachers who are not teaching their specialised subject areas and those teaching different subjects formed $50 \%$ of respondents in the rural schools. The implication is that the urban school teachers are more likely to teach effectively since they have specialised skills and knowledge in the subjects they are currently teaching. This confirms Brunner (1966) that people come out best when they are put to do what they can do better.

Furthermore, $59.5 \%$ of the students responded affirmatively that teachers' response to lessons is encouraging with only $11.7 \%$ being on the contrary. It is also seen that most students (64.1\%) in the periurban areas accept that their teachers' response to lessons is encouraging. Similarly the urban students (60.0\%) accept it. About $34.4 \%$ of the total responses of the rural schools indicate that their teachers' response to lessons is not encouraging. This suggeststhat teachers in rural schools are less likely to motivate their students to achieve good results.

\subsection{Learning and learning methods}

\section{Subject combination}

The study shows that the students have a limited choice in elective subjects because the schools do not offer them exposure to all the disciplines; this is a limitation on the creative development of the students' full potential towards a future vocation in the Visual Arts. With the variety of subject combinations in the urban schools, urban students have ample of choices, but to the peri-urban and rural students, theirs is a Hobson's choice. The implication is that students in the peri-urban and rural schools will be limited in skills and knowledge acquisition since they do not have enough subject options. This lack of choices limits the motivation students brought to undertake the programme (Kochar, 2004; Curzon, 1996) Also, students in the peri-urban and rural schools have a limited choice in gaining admission into higher institutions owing to the low grades they have in their two electives. However, those in the urban schools can choose the best two out of the three electives to help them gain admission to higher education.

Table 7

Combination of elective subjects studied by students

\begin{tabular}{|c|c|c|c|c|c|c|c|c|}
\hline \multirow{3}{*}{ Elective Subjects } & \multicolumn{8}{|c|}{ Location of School } \\
\hline & \multicolumn{2}{|c|}{ Urban } & \multicolumn{2}{|c|}{ Peri-urban } & \multicolumn{2}{|l|}{ Rural } & \multicolumn{2}{|l|}{ Total } \\
\hline & Freq & $\%$ & Freq & $\%$ & Freq & $\%$ & Freq & $\%$ \\
\hline $\begin{array}{l}\text { Graphic Design, } \\
\text { Picture-making and } \\
\text { GKA }\end{array}$ & 12 & 27.3 & 15 & 38.4 & - & - & 27 & 23.3 \\
\hline $\begin{array}{l}\text { Graphic Design, } \\
\text { Textiles and GKA } \\
\text { Graphic Design, }\end{array}$ & 11 & 25.0 & 21 & 53.9 & 8 & 24.2 & 40 & 34.5 \\
\hline $\begin{array}{l}\text { Picture-making, } \\
\text { Sculpture and GKA }\end{array}$ & 8 & 18.2 & - & - & - & - & 8 & 6.9 \\
\hline $\begin{array}{l}\text { Graphic Design, } \\
\text { Picture-making, } \\
\text { Textiles and GKA }\end{array}$ & 13 & 29.5 & - & - & - & - & 13 & 11.2 \\
\hline $\begin{array}{l}\text { Textiles, Picture-making } \\
\text { and GKA }\end{array}$ & - & - & 3 & 7.7 & 4 & 12.1 & 7 & 6.0 \\
\hline $\begin{array}{l}\text { Graphic Design, } \\
\text { Ceramics and GKA }\end{array}$ & - & - & - & - & 21 & 63 & 21 & 18.1 \\
\hline Total & 44 & 100 & 39 & 100 & 33 & 100 & 116 & 100 \\
\hline
\end{tabular}


According to the students interviewed, the teachers' response to lessons in the rural schools is not encouraging. Observation confirmed that either the teachers come to class late and leave on time or they teach into the next period or come in early and leave early. Also, teachers especially those in the rural schools, come to class without any textbooks; their attendance to classes and lessons are usually not planned. For effective learning to take place, teachers are expected to carefully plan procedures and activities that the students will undergo (Singh and Rana, 2004), but teachers in the selected schools go to class without any prepared lesson plan. They also use the latter part of the lesson for chatting and doing other things not related to the subject matter. This attitude can minimize achievement and performance.

School culture, as in outdoor activities like speech days, is known to be very important for school improvement (Wheeler and Richey, 2005). Wellbehaved and brilliant students can be celebrated on such occasions. The findings suggest that a little over half the student population in the selected schools had not ever witnessed any speech and prize giving days in their schools. However, an overwhelming majority (94.9\%) of the sampled students in the urban schools responded that they had witnessed occasions when the Visual Arts department exhibited their works on speech days. Contrary to this, an overwhelming majority $(94.4 \%)$ of students in the peri-urban and rural schools indicated that they had never witnessed a speech day before.

\section{Conclusions}

Although the study was done on a small scale, the data presented points to an urban-rural bias in the development of Senior High Schools and diversity of programmes offered the students in those schools. The disparity between the geographic locations of the schools seems to reflect the differences in resources. The Visual Arts programme in particular seems to be suffering so much in terms of lowered criteria for students admission, inadequate funding for the various elective areas, high number of instructional periods handled by few teachers in the respective subjects of specialization, unfair distribution of social infrastructure, and funding for the programme to enable the teachers have adequate resources to teach the students.

The number of elective Visual Arts subjects offered in the schools also places serious limitations on the knowledge and skills that the students could absorb on the programme. In view of these limitations, the peri-urban and rural schools have poor output while the urban schools do well and score high grades in the WASSCE. The identified differences between the schools have to be resolved through adequate resourcing, infrastructure, and effective leadership in order to address the rural- urban disparity and enhance academic achievement for students across the country.

\section{References}

Amissah, P. A. K., Sam-Tagoe, J., Amoah, S. A. and Mereku, K. D., (2002). Teacher Education: Its Principles and Practice, Faculty of Professional Studies in Education, University of Education, Winneba, Ghana.

Crocker, K. R., (1991).'Understanding the Dynamics of Classroom Behaviour' In Short, H.R., Stewin, L. L. \& McCann, J. H. S (1991). Educational Psychology: Canadian perspective, Copp Clark Pitman Ltd.

Curzon, L. B., (1996). Teaching in Further Education: An Outline of Principles and Practice, Redwood Books, Trowbridge.

Evans-Solomon, F., (2004). Girl Child Education in Visual Arts: Opportunity and Challenges, M.A Thesis, Department of General Arts Studies, KNUST.

Hayford, B.K., (1998). Re-conceptualisation of Teaching Methodology: Alternative Views for Basic School Teachers in Ghana, Journal of Consultative Council of Teachers Association, Vol. 1, No.3, pp.15-16.

James, P. ,(1996). The Construction of Learning and Teaching in a Sculpture Studies Class, Studies in Art Education, Vol. 37,No. 3,pp. 145-159.

King, K., (1990). "The Character of Schooling in SubSaharan Africa" in Enstwistle, N. (1990). Hand Book of Educational Ideas and Practice, Routledge, London.

Kochhar, S. K., (2004). Methods \& Techniques of Teaching. Sterling Publishers Pvt. Ltd., New Delhi.

Ministry of Education Science and Sports: Curriculum Research and Development Division (CRDD), September 2008, Accra, Ghana. 
Nyman, L. A. and Jenkins, M. A., (ed) (1999). "Current Trends in Education for Students with Special Needs" in Issues and Approaches to Art Students with Special Needs, NAEA, 1916 Association Drive, Reston, Virginia.

Opoku-Asare, N. A. A., (2000). Using Non-Book Instructional Materials to Promote Quality Teaching and Learning in Ghanaian Primary Schools - Rhetoric and Reality,MPhil Thesis, University Of Sussex, Brighton.

Page, T., (2007). Conception of Art Education Programmes Held By Rural and Remote Australian Community, Journal of Issues and Research, Vol. 49, No. 1,pp. 42-58.

Ryan, K. and Cooper, M. J., (1992). Those Who Can Teach ( $6^{\text {th }}$ edn.).,Houghton Mifflin Company, U.S.A.
Short, H. R., Stewin, L. L. and McCann, J. H. S., (1991). Educational Psychology:Canadian Perspective, Copp Clark Pitman Ltd.

Singh, R. P. and Rana, G., (2004). Teaching Strategies, APH Publishing Corp, New Delhi.

Von Glasersfield, E., (1995). Radical Construction, Palmer, London.

Vijayalakshmi, S. K., (2004). 'Teaching Strategies: Present Practices and Future Direction' inSingh, R. P. \& Rana, G. (2004). Teaching Strategies, APH Publishing Corp. ,New Delhi.

Wheeler, J. J. and Richey, D.D., (2005). Behaviour Management: Principles andPractice of Positive Behaviour Supports, Pearson Education, Inc., Upper Saddle River, New Jersey.

Wiggins, R., and McTighe, J., (2005). Understanding by Design, $\left(2^{\text {nd }}\right.$ edn), Prentice Hall, New York. 